\title{
NURSES' ATTITUDE TOWARD PEDIATRIC END OF LIFE CARE AT HIWA CANCER HOSPITAL IN SULAIMANY-IRAQ
}

\author{
Shadan Zahid Abdalrahman ${ }^{1}$, Bahar Nasradeen Majeed ${ }^{2 *}$ \\ 1. Hiwa Cancer Hospital, City of Sulaimani, Iraq. \\ 2. Department of Pharmacology, College of Pharmacy, University of Mosul, City of Mosul, Iraq.
}

\section{Corresponding author: Shadan Zahid Abdalrahman}

Email: shadanzahid47@gmail.com

ORCID

\section{ABSTRACT}

Background: End-of-life care refers to all aspects of the care relating to dying, and bereavement which are provided towards the end of life, end of life care is nowadays essential in nursing care, due to the increasing number of patients who require attention in the final stages of their life, the negative attitude among nurses is one of the most common barriers to the quality end of life care.

Objective: To assess attitude of the nurses working at Hiwa Cancer Hospital toward pediatric end of life care in Sulaimani city.

Methods: Quantitative Method / Descriptive Cross-Sectional Study has been carried out on (111) nurses working in Hiwa cancer hospital. Data were collected using standard questionnaires (Frommelt Attitude toward Care of the Dying scale ) data analyzed using statistical package of social science version (24).

Results: The findings of present study demonstrate that $57.3 \%$ of nurses had good attitude, $14.2 \%$ fair attitude and $28.3 \%$ poor attitude toward end of life care, with the total mean and standard deviation $(2.345 \pm 0.68)$ which indicated that nurses have good level of attitude as general, results show that level of education, work place, received training course about end of life care, attending seminar, workshop about pediatric end of life care had significant association with the attitude of nurses towards pediatric end of life care.

Conclusion and Recommendation: Overall nurses have good attitude about end of life care. It's essential for nurses who were at fair or poor attitude about end of life care to be familiarized with the concepts of end-of-life care through trainings, workshops and formal or informal education in both academic and hospital settings.

Key words: Attitude, Nurses, End of life care

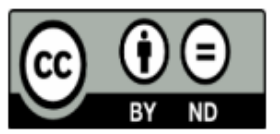

This work is licensed under a Creative Commons Attribution Non-Commercial 4.0 International License.

Received: 23 October 2021, Accepted: 07 December 2021, Available online: 20 January 2022 


\section{INTRODUCTION}

End-of-life care (EoLC) refers to all parts of care linked to dying, and grief that are offered towards the end of a person's life. People who are nearing the end of their lives and have stopped treatment to cure or control their disease are considered to be in need of end-oflife care. Palliative care and hospice care are two models of end-of-life care. End-of-life care aims to prevent or relieve suffering by managing pain and other symptoms as well as providing psychological, social, spiritual, and physical support. 57.4 million people die each year in the world, with a significant proportion of their deaths being accompanied by suffering that requires high-quality and compassionate end of life care (Abate et al., 2019).

In pediatrics, end-of-life care is defined as the support and care offered to the child and family when a child's clinical condition has progressed to the point that the child is dying or is expected to die soon. Every year in the United State, 20,000 children aged 1 to 18 years die from severe disease and they do not get high-quality end-of-life care. (Johnston et al., 2017).

Life-threatening diseases like cancer cause a decrease in the quality of life and they bring about various problems including physical, mental, and spiritual issues, as well as pain, in patients with diseases that cannot be treated despite the advances in medicine, approaches aiming at reducing the patient's distress and improving the quality of life should be applied, in accordance with this view, the approach of end of life care has been developed in order to meet the needs of patients and their relatives (Bilal, 2018).

Nurses spend more time with patients and families than other professions, according to a comprehensive study published in 2016, nurses are the most prevalent interventionists working in teams or as solo practitioners, Nurses' feelings of inadequate preparation and stress lead to the development of negative attitudes about death and caring for the dying, which may have an impact on the standard of care (Etafa et al., 2020).

One of the most essential variables impacting delivery of palliative health care is the knowledge, attitudes, beliefs, and experiences of health care providers, which influence not only their method but also their behavior during patient assessment and treatment. Nurses are the most important members of the team because they deal with the physical, functional, social, and spiritual aspects of care of the pediatric patients (Ayed, 2015).
Personal characteristics of nurses like age, years of work experience in nursing, end-of-life care training, educational level, and direct experience in caring for a dying patient or family member are described in a systematic review article as personal factors associated with better knowledge of end-of-life care and more positive attitudes toward end of life care (Prompahakul et al., 2020).

\section{METHOD}

Design of the study: Quantitative Method / Descriptive Cross-Sectional Study have been employed to undertake this research.

Setting of the study : This study was carried out at Hiwa Cancer Hospital, this hospital is the only hospital in Sulaimani City that receives patients with oncology and hematology disorders, all services offered in the hospital are free of charge for every patient. It has 142 beds and fifteen inpatient and outpatient wards, three of which are dedicated to pediatric patients and offer diagnostic, management, and follow-up care.

Sample and Sampling process: Convenient sample technique will be used for the purpose of data collection, sample size of (111) nurses selected to participate in current study for data collection ,the nurses were chosen according to inclusion criteria which are nurses work in Hiwa cancer hospital, and nurses willing to participate in the study.

Tools of the study: A questionnaire form was used for data collection consist of two parts: part one developed by the researcher composed of nurses' socio-demographic characteristics, and nurse's familiarity concerning their professional experience and part two was standard tool about Frommelt Attitudes Towards Care of the Dying (FATCOD) which consist of 24 items with 5 point Likert scale. 1 = strongly disagree, $2=$ disagree, 3 = unsure, $4=$ agree, and 5 = strongly agree. 12 of the items were written positively and the rest 12 items written negatively, the score of negative items were reversed to calculate the attitude.

\begin{tabular}{|c|c|c|c|c|}
\hline Items & Scales & $\begin{array}{c}\text { Score } \\
s\end{array}$ & $\begin{array}{l}\text { Weight } \\
\text { average } \\
\text { (mean) }\end{array}$ & Results \\
\hline \multirow{3}{*}{$\begin{array}{l}\text { Attitudes } \\
\text { for }(24) \\
\text { question } \\
\mathrm{s}\end{array}$} & $\begin{array}{c}\text { Poor } \\
\text { attitudes }\end{array}$ & 1 & $1.0-1.66$ & $\begin{array}{c}\text { Poor } \\
\text { attitudes }\end{array}$ \\
\hline & $\begin{array}{c}\text { Fair } \\
\text { attitudes }\end{array}$ & 2 & $1.66-2.33$ & $\begin{array}{c}\text { Fair } \\
\text { attitudes }\end{array}$ \\
\hline & $\begin{array}{l}\text { Good } \\
\text { attitudes }\end{array}$ & 3 & $2.34-3.00$ & $\begin{array}{l}\text { Good } \\
\text { attitudes }\end{array}$ \\
\hline
\end{tabular}

Statistical analysis

The collected data were compiled and analysed using percentages, mean, median, and $\mathrm{Chi}$-square tests using SPSS version 20. $P$ values of 0.05 were 
used as a cut-off point for the significance of the statistical test.

\section{RESULTS}

Table (1) shows that majority of sample their age ranged between 26-35 years old which account $57.7 \%$, while only $12.6 \%$ of sample their age was less than 26 years old, about gender highest percentage of sample $56.8 \%$ were female and the rest of sample was male. $52.3 \%$ of the participants were graduated from technical institute follow by $35.1 \%$ of sample graduated from college, and only $5.4 \%$ of sample was graduated from preparatory nursing school.

Table (2) represents the nurse's familiarity according to their professional experience. the highest percentage of the sample $69.4 \%$ their experience in nursing as general ranged between one to ten years, as well as only $9.9 \%$ of sample their experience was more than 20 years, while nurses experience in palliative care record only $30.6 \%$ among that $73.5 \%$ of them were had experience about $1-3$ years and lowest percentage of them which account $26.5 \%$ were had experience about 4-6 years.

in regard to nurses workplace highest percentage of the sample which accounts $21.6 \%$ were working in pediatric ward, it's worth to mention that only a few percentages $5.4 \%$ of nurses were working in the palliative care unit,

Concerning the care of patients at end of life stage, the highest percentage of nurses $81.1 \%$ cared for patients at end of life stage, and only $18.9 \%$ were not faced with any patients at end of life stage.

Regarding nurses attending training courses about the end of life care, only $28.8 \%$ of the sample were attended training courses about the end of life care and among those $23.4 \%$ of them were attended training courses inside the country, about the duration of course 59.38 \%of sample their course was about 1 to 5 days.

In addition to that highest percentage of sample, $65.8 \%$ never read article or brusher about the end of life care, as well as $79.3 \%$ of the sample, were not attended any seminar or workshop about the pediatric end of life care.

Table (3) reveal the distribution of nurses according to their attitude in five Likert scales and in three level of attitude, it shows that out of twenty-four items nurses have good attitude in twelve items, fair attitude in nine-item and poor attitude in three items, with total mean and standard deviation $2.345 \pm 0.68$ and good level of attitude in general.

Table (4) shows that statistically significant association were found between nurses attitude about end of life care with level of education $(p=0.015)$ because the result of the $p$-value was less than the common alpha 0.05. But there were no statistically significant association between nurses attitude about end of life care with gender $(p=0.225)$, age $(p=0.346)$ and years of experience $(p=0.277)$.

Table (5) Explore the association between nurse's attitude about end of life care and nurse's familiarity according to their professional experience .it shows that statistically highly significant association were found between nurse's attitude with nurses work place, while significant association found between receiving training course $(p=0.006)$, and attending seminar or workshop $(p=0.006)$, about end of life care with nurses attitude, statistically no significant association were found between nurses attitude with nurses experience of working in palliative care unit, care for patients at the end of life stage, read articles/brochures/books about end of life care.

Table 1. Distribution of the sample according to their Socio demographic characteristics

\begin{tabular}{|c|c|c|c|}
\hline Variables & Items & Frequency & $\%$ \\
\hline \multirow{4}{*}{ Age } & $>26$ years old & 14 & 12.6 \\
\hline & $26-35$ years old & 64 & 57.7 \\
\hline & $<35$ years old & 33 & 29.7 \\
\hline & Mean $\pm S . D$ & \multicolumn{2}{|c|}{$33.35 \sim 35 \pm 7.93$} \\
\hline \multirow{3}{*}{ Gender } & Male & 48 & 43.2 \\
\hline & Female & 63 & 56.8 \\
\hline & Preparatory nursing school & 6 & 5.4 \\
\hline \multirow{4}{*}{$\begin{array}{c}\text { Level of education / graduated } \\
\text { from }\end{array}$} & Institute & 58 & 52.3 \\
\hline & College & 39 & 35.1 \\
\hline & Higher education & 8 & 7.2 \\
\hline & Total & 111 & 100 \\
\hline
\end{tabular}

Table 2. Distribution of nurse's familiarity according to their professional experience

\begin{tabular}{|c|c|c|c|}
\hline Variables & Items & Frequency & $\%$ \\
\hline \multirow{3}{*}{ Years of experience in nursing professional } & $1-10$ years & 75 & 67.6 \\
\hline & $11-20$ years & 25 & 22.5 \\
\hline & More than 20 years & 11 & 9.9 \\
\hline
\end{tabular}


Do you have an experience of working in palliative care unit?

If yes How long your experience?

\section{working place}

Have you ever attended or received training about end of life care?

If yes

Where did you attend training about end of life care?

How many days

Did you care for patients at the end of life stage?

Have you ever read articles/brochures/books about end of life care?

Have you ever attended any seminar, workshop about pediatric end of life care?

\begin{tabular}{|ccc|}
\hline Mean \pm S.D & $10.38 \sim 10$ & \pm 7.44 \\
Yes & 34 & 30.6 \\
No & 77 & 69.4 \\
$1-3$ & 25 & 73.5 \\
$4-6$ & 9 & 26.5 \\
Pediatric & 24 & 21.6 \\
\hline Pediatric outpatient & 4 & 3.6 \\
Pediatric isolation & 5 & 4.5 \\
Oncology & 14 & 12.6 \\
Hematology & 16 & 14.4 \\
Male outpatient & 12 & 10.8 \\
Female outpatient & 13 & 11.7 \\
BMT & 12 & 10.8 \\
Adult isolation & 5 & 4.5 \\
Palliative & 6 & 5.4 \\
Yes & 32 & 28.8 \\
No & 79 & 71.2 \\
Inside country & 26 & 23.4 \\
Outside country & 6 & 5.4 \\
1 -5 days & 19 & 59.38 \\
More than 5 days & 13 & 40.63 \\
Yes & 90 & 81.1 \\
No & 21 & 18.9 \\
Yes & 38 & 34.2 \\
No & 73 & 65.8 \\
Yes & 23 & 20.7 \\
No & 88 & 79.3 \\
& $\mathbf{1 1 1}$ & $\mathbf{1 0 0}$ \\
\hline
\end{tabular}

Table 3. distribution of sample concerning nurse's attitude about end of life care

\begin{tabular}{|c|c|c|c|c|c|c|c|c|c|c|c|}
\hline Questions & $\begin{array}{l}\text { SDA } \\
\text { F }\end{array}$ & $\begin{array}{l}\text { DA } \\
\text { F }\end{array}$ & UN & $\begin{array}{c}\mathrm{AG} \\
\mathrm{F}\end{array}$ & SAG & $\begin{array}{l}\text { Mean } \\
\text { (S.D) }\end{array}$ & P.A & F.A & G.A & $\begin{array}{l}\text { Mean } \\
\text { (S.D) }\end{array}$ & L.A \\
\hline 1. Palliative care is given only for dying patient. & 6 & $\begin{array}{c}16 \\
14.4\end{array}$ & $\begin{array}{c}29 \\
261\end{array}$ & 40 & $\begin{array}{l}20 \\
18\end{array}$ & 3.47 & $\begin{array}{c}60 \\
541\end{array}$ & 29 & $\begin{array}{c}22 \\
198\end{array}$ & $\begin{array}{l}1.66 \\
(0.79)\end{array}$ & P.A \\
\hline $\begin{array}{l}\text { 2.As a patient nears death; the nurse should } \\
\text { withdraw from his/her involvement }\end{array}$ & 28.8 & 52.3 & 9.9 & 3.6 & 5.4 & (1.01) & 9 & 9.9 & 81.1 & $\begin{array}{c}2.72 \\
(0.62)\end{array}$ & G.A \\
\hline \multirow{3}{*}{$\begin{array}{l}\text { 3. Giving nursing care to the chronically sick } \\
\text { patient is a worthwhile learning experience. } \\
\text { 4.It is beneficial for the chronically sick person } \\
\text { to verbalize his/her feelings }\end{array}$} & 2 & 1 & 10 & 50 & 48 & 4.27 & 3 & 10 & 98 & \multirow{2}{*}{$\begin{array}{l}2.86 \\
(0.42)\end{array}$} & \multirow{2}{*}{ G.A } \\
\hline & 1.8 & 0.9 & 9 & 45 & 43.2 & $(0.8)$ & 2.7 & 9 & 88.3 & & \\
\hline & 0 & 2 & 6 & 43 & 60 & 4.45 & 2 & 6 & 103 & $\begin{array}{l}2.91 \\
(0.34)\end{array}$ & G.A \\
\hline $\begin{array}{l}\text { 5. Family members who stay close to a dying } \\
\text { person often interfere with a professionals' job } \\
\text { with the patient. }\end{array}$ & 0.9 & 5.4 & 21.6 & 42.3 & 29.7 & $(0.92)$ & 6.3 & 21.6 & 72.1 & $\begin{array}{l}2.66 \\
(0.6)\end{array}$ & G.A \\
\hline \multirow{3}{*}{$\begin{array}{l}\text { 6. The length of time required to give nursing } \\
\text { care to a dying person would frustrate me. } \\
\text { 7.Families should be concerned about helping } \\
\text { their dying member to make the best of his/her } \\
\text { remaining life. }\end{array}$} & $\begin{array}{c}8 \\
7.2\end{array}$ & $\begin{array}{c}52 \\
46.8\end{array}$ & $\begin{array}{c}23 \\
20.7\end{array}$ & $\begin{array}{c}21 \\
18.9\end{array}$ & $\begin{array}{c}7 \\
6.3\end{array}$ & $\begin{array}{c}2.7 \\
(1.05)\end{array}$ & $\begin{array}{c}28 \\
25.2\end{array}$ & $\begin{array}{c}23 \\
20.7\end{array}$ & $\begin{array}{c}60 \\
54.1\end{array}$ & $\begin{array}{l}2.29 \\
(0.85)\end{array}$ & F.A \\
\hline & 1 & 2 & 5 & 45 & 58 & 4.41 & 3 & 5 & 103 & \multirow{2}{*}{$\begin{array}{c}2.9 \\
(0.38)\end{array}$} & \multirow[b]{2}{*}{ G.A } \\
\hline & 0.9 & 1.8 & 4.5 & 40.5 & 52.3 & $(0.74)$ & 2.7 & 4.5 & 92.8 & & \\
\hline \multirow{4}{*}{$\begin{array}{l}\text { 9. The nurse should not be the one to talk about } \\
\text { death with the dying person. } \\
\text { 10.The family should be involved in the } \\
\text { physical care of the dying person. } \\
\text { 11.It is difficult to form a close relationship with } \\
\text { the family of a dying member. }\end{array}$} & 0 & 6 & 7 & 47 & 51 & 4.28 & 98 & 7 & 6 & & P.A \\
\hline & 0 & 5.4 & 6.3 & 42.3 & 45.9 & $(0.81)$ & 88.3 & 6.3 & 5.4 & & \\
\hline & 9 & 35 & 37 & 22 & 8 & 2.86 & 30 & 37 & 44 & 2.19 & $F A$ \\
\hline & 8.1 & 31.5 & 33.3 & 19.8 & 7.2 & (1.06) & 27 & 33.3 & 39.6 & $(0.81)$ & I.A \\
\hline 12.There are times when death is welcomed by & 6 & 23 & 32 & 37 & 13 & 3.25 & 29 & 32 & 50 & 2.19 & FA \\
\hline the dying person & 5.4 & 20.7 & 28.8 & 33.3 & 11.7 & $(1.08)$ & 26.1 & 28.8 & 45 & $(0.83)$ & F.A \\
\hline 13.Nursing care for the patient's family should & 29 & 42 & 17 & 13 & 10 & 2.39 & 71 & 17 & 23 & & \\
\hline $\begin{array}{l}\text { contlnue throughout the period of griet and } \\
\text { bereavement. }\end{array}$ & 26.1 & 37.8 & 15.3 & 11.7 & 9 & $(1.25)$ & 64 & 15.3 & 20.7 & $(0.82)$ & A \\
\hline 14.The dying person and his/her family should & 1 & 7 & 10 & 39 & 54 & 4.24 & 8 & 10 & 93 & 2.88 & G.A \\
\hline be the in-charge decision makers. & 0.9 & 6.3 & 9 & 35.1 & 48.6 & $(0.93)$ & 7.2 & 9 & 83.8 & (0.57) & \\
\hline $\begin{array}{l}\text { 15.Addiction to pain relieving medication } \\
\text { should not be a nursing concern when dealing }\end{array}$ & 2 & 12 & 9 & 53 & 35 & 3. & 14 & 9 & 88 & 2.86 & A \\
\hline with a dying person. & 1.8 & 10.8 & 8.1 & 47.7 & 31.5 & (1.0) & 12.6 & 8.1 & 79.3 & ) & ת. \\
\hline
\end{tabular}


17.When a patient asks, "Nurse am I dying? I think it is best to change the subject to something cheerful.

18.I am afraid to become friends with chronically sick and dying patients

19.I would be uncomfortable if I entered the room of a terminally ill person and found him/her crying

20.I would be uncomfortable talking about impending death with the dying Person

21..It is possible for nurses to help patients prepare for $\mathrm{d}$

22.Death is not the worst thing that can happen to a person

23.I would feel like running away when the person actually died

24.I would not want to be assigned to care for a dying person

Sum: nurse's attitude about end of life care

\begin{tabular}{|ccccccccc}
0.0 & 6.3 & 3.6 & 43.2 & 46.8 & $(0.82)$ & 90.1 & 3.6 & 6.3 \\
\hline 8 & 36 & 27 & 31 & 9 & 2.97 & 40 & 27 & 44 \\
\hline 7.2 & 32.4 & 24.3 & 27.9 & 8.1 & $(1.1)$ & 36 & 24.3 & 39.6 \\
6 & 48 & 10 & 34 & 13 & 3.00 & 47 & 10 & 54 \\
\hline 5.4 & 43.2 & 9 & 30.6 & 11.7 & $(1.2)$ & 42.3 & 9 & 48.6 \\
\hline 3 & 31 & 13 & 40 & 24 & 3.46 & 64 & 13 & 34 \\
\hline 2.7 & 27.9 & 11.7 & 36 & 21.6 & $(1.19)$ & 57.7 & 11.7 & 30.6 \\
1 & 13 & 20 & 45 & 32 & 3.85 & 14 & 20 & 77 \\
0.9 & 11.7 & 18 & 40.5 & 28.8 & $(1.01)$ & 12.6 & 18 & 69.4 \\
\hline 6 & 21 & 14 & 44 & 26 & 3.57 & 27 & 14 & 70 \\
\hline 5.4 & 18.9 & 12.6 & 39.6 & 23.4 & $(1.2)$ & 24.3 & 12.6 & 63.1 \\
\hline 15 & 47 & 15 & 21 & 13 & 2.73 & 34 & 15 & 62 \\
\hline 13.5 & 42.3 & 13.5 & 18.9 & 11.7 & $(1.25)$ & 30.6 & 13.5 & 55.9 \\
\hline 17 & 40 & 15 & 25 & 14 & 2.81 & 39 & 15 & 57 \\
\hline 15.3 & 36 & 13.5 & $\mathbf{2 2 . 5}$ & $\mathbf{1 2 . 6}$ & $(1.3)$ & 35.1 & 13.5 & $\mathbf{5 1 . 4}$ \\
\hline 156 & $\mathbf{5 3 0}$ & $\mathbf{3 8 0}$ & $\mathbf{8 7 9}$ & $\mathbf{7 1 9}$ & $\mathbf{3 . 5 5}$ & $\mathbf{7 5 6}$ & $\mathbf{3 8 0}$ & $\mathbf{1 5 2 8}$ \\
\hline $\mathbf{5 . 8 6}$ & $\mathbf{1 9 . 8}$ & $\mathbf{1 4 . 2}$ & $\mathbf{3 3}$ & $\mathbf{2 6 . 9 9}$ & $(1.25)$ & $\mathbf{2 8 . 3}$ & $\mathbf{1 4 . 2}$ & $\mathbf{5 7 . 3}$ \\
\hline
\end{tabular}

Note: $\mathrm{SA}=$ strongly agree, $\mathrm{AG}=$ agree, $\mathrm{UN}=$ unsure, $\mathrm{DA}=$ disagree and SDA= strongly disagree S.D: Stander deviation, P.A : Poor attitudes, F.A: Fair attitudes. G.A: Good attitudes. L.A: level of attitude

Weight average (mean) for 3point Likert scales: 1.0-1.66 : Poor attitudes, 1.67-2.33: Fair attitudes,2.34-3.0: Good attitudes

Table 4. Association between nurse's attitude about end of life care and their Socio demographic characteristics

\begin{tabular}{|c|c|c|c|c|c|}
\hline items & $\mathbf{N}$ & Mean & S.D & Significant test & P-value \\
\hline \multicolumn{6}{|c|}{ Age } \\
\hline$>26$ years old & 14 & 2.2649 & 0.15980 & \multirow{3}{*}{$1.07^{* *}$} & \multirow{3}{*}{0.346} \\
\hline $26-35$ years old & 64 & 2.3132 & 0.19345 & & \\
\hline$<35$ years old & 33 & 2.2551 & 0.21794 & & \\
\hline \multicolumn{6}{|l|}{ Gender } \\
\hline Male & 48 & 2.3160 & 0.20875 & \multirow{3}{*}{1.222 * } & \multirow{3}{*}{0.225} \\
\hline \multirow[t]{2}{*}{ Female } & 63 & 2.2698 & 0.18781 & & \\
\hline & & \multicolumn{2}{|c|}{ Level of education } & & \\
\hline Preparatory nursing school & 6 & 2.0972 & 0.20861 & \multirow{5}{*}{$3.627^{* *}$} & \multirow{5}{*}{0.015} \\
\hline Institute & 58 & 2.2658 & 0.18680 & & \\
\hline College & 39 & 2.3472 & 0.19644 & & \\
\hline Higher education & 8 & 2.3281 & 0.17878 & & \\
\hline $\begin{array}{l}\text { Note } / /^{*} \text { is the } \\
{ }^{*} \text { is the is the }\end{array}$ & $\begin{array}{l}\text { etric } \\
\text { tric }\end{array}$ & $\begin{array}{l}\text { mples T } \\
\text { A-F-Te }\end{array}$ & & & \\
\hline
\end{tabular}

Table 5. Association between nurse's attitude about end of life care and nurse's familiarity according to their professional experience

\begin{tabular}{|c|c|c|c|c|c|}
\hline Items & $\mathbf{N}$ & Mean & S.D & Significant test & P-value \\
\hline \multicolumn{6}{|c|}{ Years of experience in nursing professional $\backslash$ employment } \\
\hline $1-10$ years old & 75 & 2.2928 & 0.19289 & \multirow{3}{*}{$1.301^{*}$} & \multirow{3}{*}{0.277} \\
\hline $11-20$ years old & 25 & 2.3183 & 0.19465 & & \\
\hline More than 20 years old & 11 & 2.2045 & 0.23008 & & \\
\hline \multicolumn{6}{|c|}{ Do you have an experience of working in palliative care unit? } \\
\hline Yes & 34 & 2.3365 & 0.18006 & \multirow{3}{*}{1.557 * } & \multirow{3}{*}{0.122} \\
\hline No & 77 & 2.2727 & 0.20654 & & \\
\hline \multicolumn{4}{|c|}{ Work place } & & \\
\hline Pediatric & 24 & 2.2708 & 0.23183 & \multirow{10}{*}{$3.843^{*}$} & \multirow{10}{*}{0.000} \\
\hline Pediatric outpatient & 4 & 2.2500 & 0.12266 & & \\
\hline Pediatric isolation & 5 & 2.2750 & 0.13372 & & \\
\hline Oncology & 14 & 2.6660 & 0.38119 & & \\
\hline Hematology & 16 & 2.5920 & 0.38925 & & \\
\hline Male outpatient & 12 & 2.5314 & 0.37697 & & \\
\hline Female out patient & 13 & 2.3971 & 0.22656 & & \\
\hline BMT & 12 & 2.2361 & 0.29212 & & \\
\hline Adult isolation & 5 & 2.2833 & 0.09033 & & \\
\hline Palliative & 6 & 2.1806 & 0.19837 & & \\
\hline \multicolumn{6}{|c|}{ Have you ever attended or received training about end of life care? } \\
\hline Yes & 32 & 2.3698 & 0.19479 & \multirow{2}{*}{2.798 * } & \multirow{2}{*}{0.006} \\
\hline No & 79 & 2.2574 & 0.19045 & & \\
\hline \multicolumn{6}{|c|}{ Did you care for patients at the end of life stage? } \\
\hline Yes & 90 & 2.2903 & 0.20664 & \multirow{2}{*}{0.054 * } & \multirow{2}{*}{0.957} \\
\hline No & 21 & 2.2877 & 0.15696 & & \\
\hline \multicolumn{6}{|c|}{ Have you ever read articles/brochures/books about end of life care? } \\
\hline Yes & 38 & 2.3140 & 0.27348 & \multirow{2}{*}{1.122 * } & \multirow{2}{*}{0.264} \\
\hline No & 73 & 2.2631 & 0.19860 & & \\
\hline \multicolumn{6}{|c|}{ Have you ever attended any seminar, workshop about pediatric end of life care? } \\
\hline Yes & 23 & 2.3779 & 0.23897 & \multirow{2}{*}{2.198 * } & \multirow{2}{*}{0.03} \\
\hline No & & 597 & 2730 & & \\
\hline
\end{tabular}




\section{DISCUSSION}

Concerning the nurses' profile, the analysis clearly indicates that more than half of the samples were female and their age ranged between (26-35) years old, with a mean of (33.35). These findings concur with the findings of a study conducted in Turkey by (Cevik \& Kav, 2013), who stated that the proportion of female nurses was higher than the proportion of male nurses, and the highest percentage of their sample's age ranged between (26-30) years old. The researchers' point of view is that nursing professionals are more acceptable by female .

Due to the fact that there have been no nurses graduating from preparatory schools of nursing in the last two decades, more than half of the nurses graduated from nursing institutes, followed by college nurses, who accounted for more than one third of the sample, and only a small percentage of the sample graduated from preparatory schools of nursing. These findings are consistent with a study done in Rwanda by (Marie Claire, 2017) in their study; the highest percentage of the sample has a diploma degree in nursing.

In terms of nurse familiarity related to professional experience, approximately twothirds of the sample had experience in nursing ranging from one to ten years with a mean of (10.38), whereas a study conducted in Kazakhstan (Tereshkova, 2021) found that the majority of their sample had twenty to twenty-nine years of experience, which contradicts the current finding. Unfortunately, more than two-thirds of the sample did not work in the palliative care unit. Their experience ranged between one to three years due to the fact that the palliative care unit was established about six years ago. It's a new unit in Hiwa Cancer Hospital. , in a study done in Indonesia by (A'la et al., 2020) found that more than half of their sample had five to ten years of experience in nursing. and the majority of nurses had experience in caring for end of life patients.

regarding nurses workplace, more than one quarter of the nurses were working in different units of the pediatric ward, like the inpatient unit, outpatient unit, and isolation unit, ,and the rest of the nurses were working in different units in Hiwa Cancer Hospital, such as the oncology unit , hematology unit, male and female outpatient units,... etc. The findings consistence with the results of study done in Taiwan by (Lin et al., 2021). They found that around one quarter of the nurses work in pediatric wards, and the majority of nurses care for patients at the end of life stage. less than one third of sample were participated in training courses, and more than half of them their training course were ranged between only one to five days which is done mostly inside the country , this result disagree with the findings of study done by (Ayed, A,2015) they found that more than half of nurses had obtained training course and the majority of them were trained for less than 1 week.

The analysis revealed that the total mean and standard deviation in all twenty-four items of nurses' attitude toward end-of-life care was $(2.35 \pm 0.68)$, indicating that nurses in Hiwa Cancer Hospital have a positive attitude toward end-oflife care. The same findings reveal that nurses have a positive attitude in twelve items, a fair attitude in nine items, and a negative attitude in three items.

Majority of participants were agreed to statements "Family should maintain as normal an environment as possible for their dying member", and "It is beneficial for the chronically sick person to verbalize his/her feelings". Only few percentage of the participants agreed to statements that "The family should be involved in the physical care of the dying person" and "When a patient asks, "Nurse am I dying? 'I think it is best to change the subject to something cheerful".

The findings of this study were congruent with a study done in Pakistan by (Parveen et al., 2020) which illustrated that most of the nurses had a favorable attitude towards end of life care. These findings were not confirmed by another study done in Sudan (Bilal, 2018). According to their results, most respondents' attitudes levels towards palliative care were moderate attitudes, but the present findings disagree with the results of another study done by (Faronbi et al., 2021) which showed that most nurses had a negative attitude towards end of life care.

The difference in mean scores may be due to the variation of beliefs and cultures among nursing staff across regions, which needs to be investigated. Another reason might be the variation in training provided for professionals in different areas.

Based on analysis for demographic data age, gender, doesn't reflect any significant association on the nurse's attitude toward palliative care, while statistically significant association were found between nurses attitude and nurses level of education at $p$ value 0.015 , this result congruent with a study done in 2019 they mention that significant association found between nurses attitude and level of education (Gedamu et al. 2019) .

In this study, no significant association was found between nurses' attitude towards end of life care with nurse's experience ,nurses' work place, while a statistically significant association was found between nurses' attitude towards end of life care with nurses who had received training course about end of life care. This result agrees with the findings of the study done by (Zewdu et al., 2017) In their results, nurses who had been trained had more likely two times favorable attitude towards end of life care as compared to those who had not been trained, but their results are inconsistent with the present study in terms of nursing experience and nurse work place .

Findings show that, statistically, no significant association was found between nurses' attitudes 
toward end of life care and those who had palliative care service experience, and nurses who had an interest in reading about end of life care. In contrast, a study reported that nurses who had palliative care service experience were less likely to show a positive attitude towards endof-life care than nurses who had no palliative service experience, and nurses who read articles/brochures about palliative care were more likely to display a positive attitude than nurses who did not read articles/brochures about palliative care ( Etafet al,. 2020).

In addition to that, there was no association between nurses' attitudes with nurses who cared for patients at the end of life stage, which is incompatible with the result of the study done by Abate and colleagues (Marie Claire , 2017). Also, significant associations were found between nurses' attitudes and nurses who attended seminars and workshops about pediatric end of life care.

\section{CONCLUSIONS}

Overall nurses have good attitude about end of life care, it's essential for nurses who were at fair or poor attitude about end of life care to be familiarized with the concepts of EoLC through trainings, workshops and formal or informal education in both academic and hospital settings.

\section{ETHICAL CONSIDERATIONS COMPLIANCE WITH ETHICAL GUIDELINES}

This study was accepted by the Scientific Committee at the College of Nursing, accordingly approved by ethical committee at College of Medicine/University of Sulaimani. An official letter has been submitted from the College of the Nursing/University of Sulaimani to the General Directorate of Health (DOH) in Sulaimani City to get agreement for data collection for the current study Consequently, an agreement letter has been submitted from (DOH) to Hiwa Cancer Hospital.

\section{FUNDING}

This research did not receive any grant from funding agencies in the public, commercial, or non-profit sectors.

\section{AUTHOR'S CONTRIBUTIONS}

Study concept; Writing the original draft;D ata collection; Data analysis and Reviewing the final edition by the author.

DISCLOSURE STATEMENT: The authors report no conflict of interest.

ACKNOWLEDGEMENTS: The researchers are grateful to the nurses in the Hiwa Cancer Hospital for the participation in this study.

\section{REFERENCES}

Abate, A., Amdie, F., Bayu, N., Gebeyehu, D., \& G/Mariam, T. (2019). Knowledge, Attitude And Associated Factors Towards End Of Life Care Among Nurses' Working In Amhara Referral Hospitals, Northwest Ethiopia: A Cross-Sectional Study. Bmc Research Notes, 12(1). Https://Doi.Org/10.1186/S13104-019-4567-7.

A'la M, Farikhah Z, Hakam M. (2020 ) Nurses' Attitude Toward End of Life Care in Emergency Departement and Intensive Care Unit In Rural Hospital. IJNP (Indonesian Journal of Nursing Practices).;4(1) DOI:10.18196/ijnp.41103.

Ayed, A. (2015). The Nurses' Knowledge And Attitudes Towards The Palliative Care. Journal Of Education And Practice, 6(4). Retrieved 22 April 2021.

Bilal, M. (2018). The Knowledge Of Palliative Care And The Attitude Toward It Among The Nurses At Sabia General Hospital 2018. Sudan Journal Of Medical Sciences, 13(4), 301. Https://Doi.Org/10.18502/Sjms.V13i4.3606.

Cevik, B., \& Kav, S. (2013). Attitudes And Experiences Of Nurses Toward Death And Caring For Dying Patients In Turkey. Cancer Nursing, 36(6),

E58-E65. Https://Doi.Org/10.1097/Ncc.0b013e318276924c

Etafa, W., Wakuma, B., Fetensa, G., Tsegaye, R., Abdisa, E., \& Oluma, A. Et Al. (2020). Nurses' Knowledge About Palliative Care And Attitude Towards End- Of-Life Care In Public Hospitals In Wollega Zones: A Multicenter Cross-Sectional Study. Plos One, 15(10), E0238357https://Doi.Org/10.1371/Journal.Pone. 0238357.

Faronbi, J., Akinyoola, O., Faronbi, G., Bello, C., Kuteyi, F., \& Olabisi, I. (2021). Nurses' Attitude Toward Caring for Dying Patients in a Nigerian Teaching Hospital. SAGE Open Nursing, 7, 237796082110052.

https://doi.org/10.1177/23779608211005213.

Gedamu S, Berhane E, Dires A, Anteneh S, Goshiye D, Et Al. (2019) Knowledge And Attitude Of Nurses Towards Palliative Care In Government Hospitals Of Addis Ababa,Ethiopia.Jnurscare8:486 Http://Localhost:80/Xmlui/Handle/123456789/9 331. 
Johnston, E., Rosenberg, A., \& Kamal, A. (2017). Pediatric-Specific End-Of-Life Care Quality Measures: An Unmet Need Of A Vulnerable Population. Journal Of Oncology Practice, 13(10), E874-E880.

Https://Doi.Org/10.1200/Jop.2017.021766.

Lin, H., Chen, C., Lu, C., Lin, S., \& Huang, C. (2021). Nurses' Knowledge, Attitude, And Competence Regarding Palliative And End-Of-Life Care: A Path Analysis. Peerj, 9, E11864. Https://Doi.Org/10.7717/Peerj.11864.

Marie Claire K. (2017) 'Assessment Of Nurses' Knowledge And Attitude About Palliative Care Among Nurses At University Teaching Hospital Of Kigali"College Of Medicine And Health Sciences . Available From: Http://Hdl.Handle.Net/123456789/285.

Parveen, A., Sultana, K., Waqas, A., Tasneem, S., Jabeen, R., Faiz, A., \& Faiz, A. (2020). Knowledge And Attitude Of Nurses About Palliative Care. Journal Of Bioresource Management, 7(1), 68-73. Https://Doi.Org/10.35691/Jbm.0202.0122.

Prompahakul C, Nilmanat K, Kongsuwan W. (2011) Factors Relating To Nurses' Caring Behaviors For Dying Patients. Nurse Media J Nurs.;1(1):15-27. Doi:10.14710/Nmjn.V1i1.744.

Tereshkova, G. (2021). Nurses' Knowledge And Attitudes To Palliative Care. Urn.Fi. Retrieved 6 December 2021, From Https://Urn.Fi/Urn:Nbn:Fi:Amk-2020082519860.

Zewdu, F., Kassa, H., Hailu, M., Murugan, R., \& Woldeyohannes, D. (2017). Knowledge, Attitude And Practice And Associated Factors Towards Palliative Care Among Nurses Working In Selected Hospitals, Addis Ababa, Ethiopia. European Journal Of Cancer, 72, S161. Https://Doi.Org/10.1016/S0959-8049(17)30599-

3. 